\title{
Editorial da terceira edição de 2019
}

Nossa terceira e última edição de 2019 apresenta artigos com objetos e temas variados, com perspectivas epistemológicas, teóricas e metodológicas ainda mais diversas. Apesar de tal diversidade, todos eles fortemente repercutem o atual momento econômico, político e acadêmico que vivenciamos, elencando aspectos centrais da contemporaneidade. É relevante destacar tais aspectos porque recorrentemente a área de administração é acusada de se abster dos debates das esferas política e social, mesmo quando tais debates condicionam a estrutura, processo e cultura das organizações.

Esse debate é pouco recorrente porque ainda há a crença de que aspectos políticos e ideológicos comprometem a imparcialidade acadêmica. Pelo contrário, estudar como as organizações estão imersas em tais aspectos não implica em abandonar uma postura analiticamente crítica: trazer a política e a sociedade de volta para a teoria das organizações remete em maior capacidade de se explicar os fenômenos organizacionais. Afinal, apesar de serem "gaiolas de ferro", as organizações servem a interesses que emergem de grupos com as mais variadas posições ideológicas, não somente ao da ideologia da racionalidade econômica.

Um bom exemplo desse debate é o primeiro artigo desta edição, que ilustra como corporações atuam estrategicamente no campo automotivo. Intitulado "O Campo Transnacional da Inovação Tecnológica e Estratégias Relacionais de Ação", a pesquisa conduzida pelos pesquisadores Paulo Cesar Matui, Roniberto Morato do Amaral, Mário Sacomano Neto e Silvio Eduardo Alvarez Candido investiga a influência de novas tecnologias na estrutura relacional do campo da indústria automotiva. Por meio da análise semântica e de dados longitudinais de patentes, os autores apontaram o padrão de escolha tecnológica antes e depois da entrada do Google no setor automotivo. As estruturas relacionais analisadas nessa pesquisa mostraram que a formação de grupos hierárquicos evidencia a ação estratégica das montadoras em estabilizar o campo da inovação tecnológica por meio do enquadramento da ação de concorrentes.

O segundo artigo trata da questão do "impacto" da pesquisa acadêmica, mais especificamente do impacto dos periódicos por meio da análise das citações. Por mais técnico e científico que pareça tal debate, ele ganhou relevância no momento atual, porque, em pleno século $X X I$, questiona-se ainda o papel da ciência e da academia. E, ao invés de se destacar a importância da ciência enquanto esfera parcialmente autônoma, o debate vem se fechando muito mais em questões acerca do impacto tecnológico da ciência do que nela propriamente dita. Assim, Rodrigo Assunção Rosa e Marcello Romani-Dias, no artigo "A Presença e o Impacto de Periódicos Brasileiros da Área de Administração, Contabilidade e Turismo em Bases Científicas", buscam levantar a classificação dos periódicos brasileiros de administração, contabilidade e turismo nas bases que calculam fator de impacto. Os autores encontraram reduzida presença e baixo crescimento do
Luciano Rossoni (iD,

Editor da RECADM

UniGranRio, Brasil

Irossoni@gmail.com 
impacto dos periódicos nas bases Scopus e Scielo, e crescimento razoável na Web of Science, porém oriundo principalmente de autocitações, de citações nacionais de periódicos e de citações de autores brasileiros. Verificaram também alta correlação entre diferentes medidas de impacto, bem como a inexistência de diferença significante das médias de impacto entre alguns estratos Qualis em diferentes medidas e variação considerável no impacto de um mesmo periódico em diferentes bases internacionais e nacionais.

No terceiro artigo, "A Socioeducação como Dispositivo de Poder Disciplinar: Histórias Vividas", Tatiane Alves de Melo e Eloísio Moulin de Souza analisam a socioeducação como dispositivo de poder disciplinar. Por meio do método biográfico, os autores se ativeram às histórias de vida de um ex-interno, considerando a medida socioeducativa de internação. Mais do que uma prática pedagógica, a socioeducação desvela-se como um dispositivo de poder disciplinar, que se expressa por meio de instrumentos, como a sanção normalizadora, a disciplina, a vigilância e o olhar hierárquico sobre o indivíduo. Entre uma das implicações mais relevantes do estudo é alertar ao leitor que mecanismos de coerção e disciplina não são exclusivos de organizações penitenciárias: eles estão presentes também no aparato do Estado e nas organizações empresariais. E como os estudos organizacionais nos mostram, eles recorrentemente operam como mecanismo de opressão e punição, ao invés de serem utilizados como mecanismo de ordem e de coordenação.

Central para o debate atual do papel das organizações e da imprensa no apoio de Estados totalitários, no quarto artigo, "Imprensa, Discurso Ideológico e Golpe de Estado: uma Análise Crítica do Discurso", as autoras Cynthia Adrielle da Silva Santos e Alessandra de Sá Mello da Costa buscaram compreender qual foi o posicionamento e as principais construções discursivas que o Jornal Folha de São Paulo assumiu no momento do golpe civil-militar de 1964. As autoras apontam que há indícios de alinhamento do posicionamento do Jornal com o golpe civil-militar de 1964 por meio de suas formações ideológicas mobilizadas pelas formas simbólicas do discurso. Sob a ótica organizacional, as autoras ilustram muito bem como o alinhamento ideológico dos controladores de organizações jornalísticas ignoraram o princípio de imparcialidade e de busca da verdade, que é inerente à atuação da imprensa, para servir a uma elite burocrático-política.

O quinto artigo, "Reflexos das Mídias Sociais na Cultura Organizacional da Polícia Militar", de autoria de Mirian Assumpcao e Lima investiga o processo de adoção das mídias sociais pela Polícia Militar de Minas Gerais, com o objetivo de compreender a influência do uso dessas ferramentas na cultura organizacional. Como bem aponta a autora, o isolamento em relação ao mundo civil é um dos traços da cultura em organizações de caráter militar. Tal isolamento se liga a outros traços como desconfiança, sentido de missão e formalismo. Assim, torna-se difícil se pensar no emprego de tecnologias de informação e comunicação que permitam uma maior interação com a comunidade. Os resultados apontaram para dois repertórios interpretativos: enquanto indivíduos, entende-se que o "WhatsApp é a mídia do policial", e enquanto atores na organização, o "Facebook é a mídia da polícia". Esses repertórios caracterizam-se por uma menor disposição à exposição pública 
por parte do policial e uma maior exposição institucional em busca de uma boa imagem pública. Tal pesquisa se mostra extremamente relevante porque não há como dissociar o papel das mídias sociais na recente politização das polícias militares no país, o que compromete a eficácia de sua atuação.

Por fim, no sexto e último artigo deste ano, "Orientação e Motivação Empreendedoras: evidências do empreendedorismo religioso", Victor Silva Corrêa investiga fatores indutores da orientação empreendedora de natureza religiosa por meio de abordagem qualitativa e estratégia de estudo de casos múltiplos holísticos. Não é de agora o engajamento de igrejas neopentecostais em atividades de fomento ao empreendedorismo dos fiéis. Além disso, mostra-se recorrente uso de técnicas de gestão para que pastores sejam mais efetivos na gestão de suas unidades.

Diferentemente de todos os editoriais anteriores que produzi na RECADM, neste editorial não tratei de nenhum tema especificamente. Isso pode frustrar alguns leitores, mas prometo que no ano de 2020 teremos editoriais temáticos cada vez mais informativos e, ao mesmo tempo, provocativos. Em parte, tal silêncio editorial é meio que proposital, pois vivenciamos um ano extremamente difícil para a academia e para a ciência brasileira, de forma geral, assim como para as instituições de ensino e pesquisa, de forma particular. Um ano que, mesmo cheio de conquistas para a RECADM, não há o que comemorar. Contudo, tal silêncio é momentâneo, usado somente para se recuperar o fôlego, pois editores de revistas acadêmicas, como um dos organizadores da comunicação científica, não podem se calar diante das constantes ameaças que o sistema universitário e a pesquisa vêm sofrendo.

Assim, despeço-me mais uma vez agradecendo o empenho dos avaliadores, o profissionalismo da equipe de suporte da RECADM, e o apoio financeiro do Instituto Brasileiro de Estudos e Pesquisas Sociais, que mantêm a revista viva. E que nosso próximo ano seja menos obscuro que o atual ano para a ciência e para a academia.

Um excelente ano e uma prazerosa leitura,

\section{Luciano Rossoni}

Editor da RECADM 